\title{
Strike-induced chemosensory searching in rattlesnakes: A rodent specialist (Crotalus viridis) differs from a lizard specialist (Crotalus pricei)
}

\author{
ERIC CRUZ, SUSAN GIBSON, KARL KANDLER, GALEN SANCHEZ, and DAVID CHISZAR \\ University of Colorado, Boulder, Colorado
}

\begin{abstract}
Prairie rattlesnakes (Crotalus viridis) exhibited a sustained high rate of tongue flicking after a predatory strike whether or not rodent odors were present in the poststrike environment. For the lizard specialist, $C$. pricei, strike-induced chemosensory searching was maintained at a high level only when chemical cues were available following the strike.
\end{abstract}

Rattlesnakes typically release adult rodents after envenomating them (Gans, 1966; Kardong, 1986; Radcliffe, Chiszar, \& O'Connell, 1980), allowing the wounded prey to wander freely while the venom takes effect (Brock, 1980; Estep, Poole, Radcliffe, O'Connell, \& Chiszar, 1981; Hayes \& Galusha, 1984). The predators then locate the dead rodents by following their chemical trails (Dullemeijer, 1961; Duvall, Chiszar, Trupiano, \& Radcliffe, 1978; Duvall, Scudder, \& Chiszar, 1980; Golan, Radcliffe, Miller, O'Connell, \& Chiszar, 1982; Reinert, Cundall, \& Busher, 1984). Most rattlesnake species are rodent specialists (Klauber, 1956), but even those that feed heavily on lizards in nature (e.g., Crotalus lepidus, Crotalus pricei) accept rodent prey in captivity (Chiszar, Radcliffe, Byers, \& Stoops, 1986). Moreover, C. lepidus and $C$. pricei handle rodents in much the same way that rodent-specializing species handle them (i.e., rodents are struck, released, and trailed) (Chiszar, Radcliffe, Byers, \& Stoops, 1986; Chiszar, Radcliffe, \& Feiler, 1986). Because these snakes usually hold lizards following the strike (personal observations), and no trail following occurs prior to swallowing them, it was surprising to observe accurate following of rodent trails by snakes that rarely perform such tasks in nature. However, Chiszar, Radcliffe, and Feiler (1986) reported a quantitative difference between behaviors of prairie rattlesnakes $(C$. viridis) and banded rock rattlesnakes ( $C$. lepidus). When rodent trails are available following a predatory strike, both species flick their tongues at high rates and follow these trails; however, when no rodent trails are available, only the prairie rattlesnakes exhibit high rates of tongue flicking and extensive searching movements after a strike. The rock rattlesnakes do so for only a few minutes after the

This work was completed while $K$. Kandler was an exchange student at the University of Colorado from Universität Tübingen, Tübingen, Federal Republic of Germany. Reprint requests should be addressed to D. Chiszar, Department of Psychology, Campus Box 345, University of Colorado, Boulder, CO 80309. strike before returning to quiescence. In other words, strike-induced chemosensory searching (SICS) is a relatively automatic consequence of a successful predatory strike in the rodent specialist, but SICS requires vomeronasal feedback in order to be maintained in the lizard specialist.

The present report compares poststrike behavior of $C$. viridis with that of another lizard specialist, the western twin spotted rattlesnake $(C$. pricei). Results indicate that $C$. pricei, like $C$. lepidus, exhibited a high level of SICS only when rodent odors were available.

\section{METHOD}

Subjects were $4 C$. viridis and $4 C$. pricei, all captured as adults and maintained in the laboratory for 3 years prior to this experiment (see Golan et al., 1982, for details concerning cages, temperature, and photoperiod). The snakes were fed only rodents (Mus musculus and neonatal Rattus norvegicus) during this period.

The study consisted of four conditions. In two of these, mice were suspended, using forceps, into the snakes' home cages (but held out of striking range) for $10 \mathrm{sec}$ and then withdrawn. Tongue flicks were recorded with hand-held counters for the next $30 \mathrm{~min}$. A petri dish containing soiled mouse bedding was placed into the cage and left there after one no-strike (NS) presentation, whereas a petri dish containing clean bedding (aspen chips) was introduced after the other NS presentation. The two remaining conditions were identical to the NS ones, except that the mouse was moved into striking range at the end of the 10sec presentation. All presentations were made on regular feeding days (snakes were fed every other week), and all snakes struck when given an opportunity. Envenomated mice were removed immediately following the strikes.

In addition to making a continuous record of tongue flicking for $30 \mathrm{~min}$, we also recorded tongue flicking for $\mathbf{1 0} \mathrm{min}$ prior to introducing the live mice (i.e., baseline data), and we continued observing the snakes after the $\mathbf{3 0} \mathrm{min}$ of recording tongue flicking until the first minute with zero tongue flicks (or for a maximum of $150 \mathrm{~min}$ ).

The four experimental conditions conform to a 2 (NS vs. Strike [S]) $\times 2$ (mouse odors absent $[\mathrm{NO}]$ vs. mouse odors present [O]) orthogonal combination. The four conditions were administered in a random order to snakes of both species. Analyses of variance (ANOVAs) were applied to the data, treating taxa as a between-subjects factor and NS versus $\mathrm{S}$ and NO versus $\mathrm{O}$ as repeated-measures factors. To increase the power of statistical tests in the ANOVAs, all interactions involving snakeswithin-species were pooled to generate a composite error term with 
$d f=18$. Nonorthogonal contrasts were used to make post hoc comparisons (error rate $=.05$ ).

\section{RESULTS}

The rate of tongue flicking was 0.6 per minute during baseline recordings, indicating that snakes were quiescent prior to mouse presentations. Mean number of tongue flicks during min 1-30 postpresentation is shown in Figure 1.

The $S$ versus NS effect was robust $[F(1,18)=51.87$, $p<.01]$, and this effect interacted with species $[F(1,18)$ $=4.68, p<.05]$. No other factors were significant in the ANOVA. Post hoc tests showed that $C$. viridis exhibited equal $S$ versus NS differences whether or not rodent odors were present $(F<1.0)$, but $C$. pricei emitted significantly more tongue flicks after $S$ presentations when mouse odors were present than when clean aspen bedding was present $[F(1,18)=4.83, p<.01]$.

The rate of tongue flicking dropped to zero (Figure 2) much sooner after NS than after $S$ presentation $[F(1,18)$ $=89.29, p<.01]$, and again this effect interacted with species $[F(1,18)=4.52, p<.05]$. No other factors were significant in this ANOVA. Post hoc tests revealed that after $S$ presentations the rate of tongue flicking by $C$. pricei dropped to zero more rapidly when mouse odors were absent than when they were present $[F(1,18)=7.07$, $p<.01]$. Tongue flicking by $C$. viridis did not differ in the two $S$ conditions $(F<1.0)$, indicating that searching continued equally long whether or not rodent odors were present.

\section{DISCUSSION}

C. pricei exhibited a weaker $\mathrm{S}$ versus NS effect than $\operatorname{did} C$. viridis, especially when rodent odors were absent. This finding may have theoretical importance because it suggests that SICS is a modal action pattern for $C$. viridis but not for $C$. pricei. Once a strike occurred in $C$. viridis, SICS rose to an asymptotic level and continued for at least $2 \mathrm{~h}$ whether or not rodent odors were present, implying that the intensity and duration of SICS did not depend on chemical feedback (Chiszar et al., 1985; Chiszar, Radcliffe, O'Connell, \& Smith, 1982; Golan et al., 1982). For $C$. pricei, on the other hand, both the intensity and duration

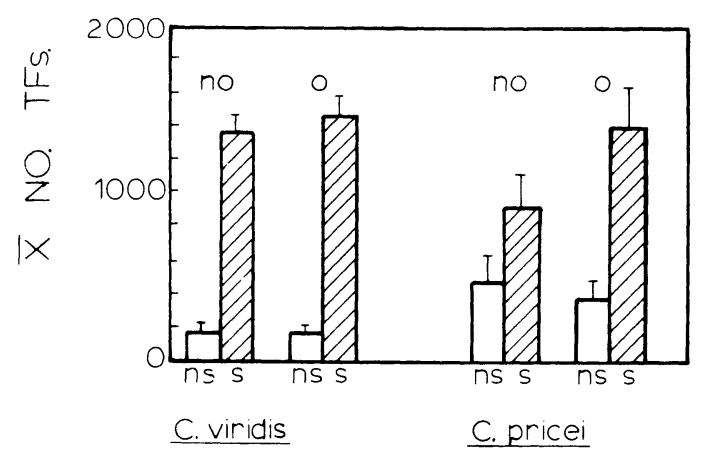

Figure 1. Mean number of tongue flicks emitted during $30 \mathrm{~min}$ following mouse presentations by 4 Crotalus viridis and $4 C$. pricei. (NS = no-strike presentation, $S=$ strike; NO = no rodent odors present, $\mathbf{O}=$ rodent odors present.) One SEM is indicated above each bar.

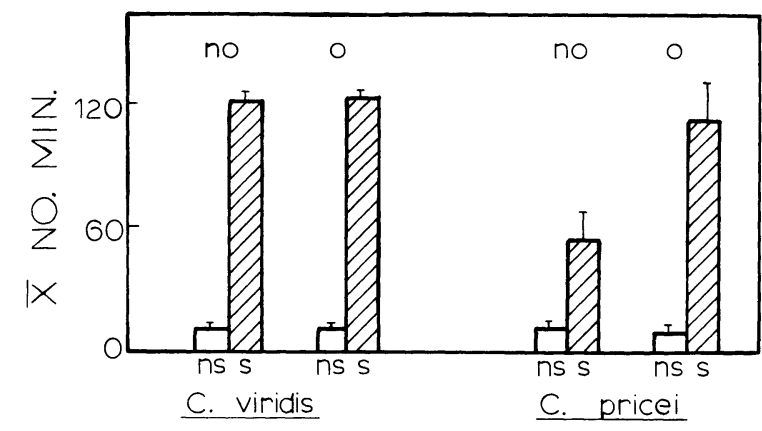

Figure 2. Mean number of minutes before the first minute with zero tongue flicks. (NS = no-strike presentation, $S=$ strike; NO = no rodent odors present, $\mathrm{O}=$ rodent odors present.) One SEM is indicated above each bar.

of SICS were enhanced by chemical cues arising from rodent-soiled bedding. Hence, SICS in $C$. pricei did not have the relatively fixed topographic properties that were observed in SICS of $C$. viridis. Chiszar, Radcliffe, Byers, and Stoops (1986) and Chiszar, Radcliffe, and Feiler (1986) suggested that dependence upon rodent prey was responsible for the strong and stereotyped SICS pattern seen in species such as $C$. viridis. The more variable SICS effect in the lizard-feeding $C$. pricei is consistent with this view, and it suggests that both $C$. pricei and $C$. lepidus retain the presumably more primitive trait of requiring chemical feedback for maintenance of a high rate of poststrike tongue flicking.

Klauber's (1956) dendrogram depicting rattlesnake evolution shows $C$. pricei along an early branch of the Crotalus tree. Other members of this branch include C. intermedius, C. lepidus, C. polystictus, $C$. pusillus, C. transversus, C. triseriatus, and $C$. willardi. Since $C$. pricei and $C$. lepidus behave similarly, with both species differing from rodent specialists, it is tempting to speculate that a correlation exists between phylogenetic status and predatory pattern or between diet and predatory pattern. Such thinking, however, must remain at the level of conjecture until additional data are accumulated on other members of this genus (Scudder, Chiszar, \& Smith, 1983).

\section{REFERENCES}

BRock, O. G. (1980). Predatory behavior of eastern diamondback rattlesnakes (Crotalus adamanteus): Field enclosure and Y-maze laboratory studies, emphasizing prey trailing behavior. Unpublished doctoral dissertation, Florida State University, Tallahassee.

Chiszar, D., O'Connell, B., Greenlee, R., Demeter, B., Walsh, T., Chiszar, J., Moran, K., \& Smith, H. M. (1985). Duration of strike-induced chemosensory searching in long-term captive rattlesnakes at National Zoo, Audubon Zoo, and San Diego Zoo. Zoo Biology, 4, 291-294.

Chiszar, D., Radcuffe, C. W., Byers, T., \& Stoops, R. (1986). Prey capture behavior in nine species of venomous snakes. Psychological Record, 36, 433-438.

Chiszar, D., Radcliffe, C. W., \& Feiler, F. (1986). Trailing behavior in banded rock rattlesnakes (Crotalus lepidus klauberi) and prairie rattlesnakes (C. viridis viridis). Journal of Comparative Psychology, 100, 368-371.

Chiszar, D., RAdcuffe, C. W., O'Connell, B., \& SMith, H. M. (1982). Analysis of the behavioral sequence emitted by rattlesnakes during feeding episodes: II. Duration of strike-induced chemosensory searching in rattlesnakes (Crotalus viridis, C. enyo). Behavioral \& Neural Biology, 34, 261-270.

DULLEMEUER, P. (1961). Some remarks on the feeding behavior of rattlesnakes. Koninklijke Nederlandische Academie von Wetenschappen (Series C), 64, 383-396.

Duvall, D., Chiszar, D., Trupiano, J., \& Radcliffe, C. W. (1978). Preference for envenomated rodent prey by rattlesnakes. Bulletin of the Psychonomic Society, 11, 7-8.

Duvall, D., Scudder, K. M., \& Chiszar, D. (1980). Rattlesnake 
predatory behavior: Mediation of prey discrimination and release of swallowing by cues arising from envenomated mice. Animal Behaviour, 28, 674-683.

Estep, K., Poole, T., RadclifFe, C. W., O'Connell, B., \& Chiszar, D. (1981). Distance traveled by mice (Mus musculus) after envenomation by prairie rattlesnakes (Crotalus viridis). Bulletin of the Psychonomic Society, 18, 108-110.

GaNs, C. (1966). The biting behavior of solenoglyph snakes-its bearing on the pattern of envenomation. Proceedings of the International Symposium on Venomous Animals. São Paulo, Brazil: Instituto Butantan.

Golan, L., Radcliffe, C. W., Miller, T., O'Connell, B., \& ChIszar, D. (1982). Prey trailing by the prairie rattlesnake (Crotalus viridis). Journal of Herpetology, 16, 287-293.

HAYES, W. K., \& GAluSha, J. G. (1984). Effects of rattlesnake (Crotalus viridis oreganus) envenomation upon mobility of male wild and laboratory mice (Mus musculus). Bulletin of the Maryland Herpetological Society, 20, 135-144.
Kardong, K. V. (1986). Predatory strike behavior of the rattlesnake, Crotalus viridis oreganus. Journal of Comparative Psychology, 100, 304-314.

KLAUBER, L. M. (1956). Rattlesnakes-Their habits, life histories, and influence on mankind. Berkeley, CA: University of California Press.

RadCliffe, C. W., Chiszar, D., O'Connell, B. (1980). Effects of prey size on poststrike behavior in rattlesnakes (Crotalus durissus, C. enyo, and C. viridis). Bulletin of the Psychonomic Society, 16, 449-450.

Reinert, H. K., Cundall, D., \& Busher, L. M. (1984). Foraging behavior of the timber rattlesnake, Crotalus horridus. Copeia, 1984, 976-981.

Scudder, K. M., Chiszar, D., SMiTh, H. M. (1983). Effect of environmental odors on strike-induced chemosensory searching by rattlesnakes. Copeia, 1983, 519-522.

(Manuscript received for publication October 17, 1986.) 